\title{
LOVE-BASED LEADERSHIP IN EARLY CHILDHOOD EDUCATION
}

\author{
Satu Uusiautti and Kaarina Määttä \\ satu@uusiautti.fi \\ University of Lapland, Finland
}

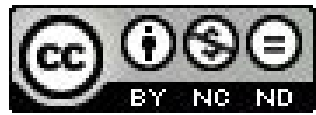

\begin{abstract}
A day care center is not just any place where children can spend their day while parents are at work. How to ensure that children have good childhood experiences and how to support their positive development from the very beginning of their educational career? In this study, we introduce the concept of love-based leadership and discuss its role and implementation in early education. Love-based leadership in early education is a method that renews teachers' professional skills. The Finnish early childhood education system offers favorable premises for love-based leadership in early education. The method should also be included in the curriculum of future early childhood education teachers.
\end{abstract}

Key words: early childhood education, early childhood education teachers, caring, pedagogical love

\section{INTRODUCTION}

Early childhood education and care can be seen as educational interaction taking place in young children's various living environments. As every preschool age child in Finland is entitled to day care, its different forms are the most important area of early childhood activities (Act on Children's Day Care, 1973/36; National Curriculum Guidelines on Early Childhood Education and Care in Finland, 2003). Well-educated staff is arguably one of the strengths of the Finnish day care system. In the day care centers, the term 'educator' refers to a person responsible for care, education, and teaching. In Finland, the legislation sets out clear requirements for staff qualifications. At least one-third of the staff must have a post-secondary level degree: Bachelor of Education, Master of Education, or Bachelor of Social Sciences (Decree on Children's Day-care, 239/1973; National Curriculum Guidelines on Early Childhood Education and Care in Finland, 2003). This is the foundation for early childhood education provided by Finnish law (see also Määttä, \& Uusiautti, 2012a).

However, staff at day care centers also have to consider many modern phenomena that threaten children's well-being (Seidl, \& Friend, 2002), and this concerns teachers in early education as well. Such phenomena are, for example, the uncertainty of the future, competitiveness, demands on individual performance levels, busyness, efficiency, strains on proficiency and success, internationalism, outsourcing of caring and nurturing, and feelings of exclusion, anxiety, and depression. Teachers 
need a new type of professional skills, such as the ability to act as future-makers in diverse school contexts that include pupils with various learning abilities and cultural backgrounds.

According to Blay and Ireson (2009), there is a link between teachers' pedagogical beliefs and their practices. Our aim in this paper is to dissect this teaching and care giving attitude through love. We have earlier claimed that love cannot be ignored when reflecting good teacherhood in every educational level (Uusiautti, \& Määttä, 2012b). For example, in Happo's (Happo, 2006; see also Happo, Määttä, \& Uusiautti, 2012) study devoted to early childhood education, love, genuine caring, and tenderness were described as significant components of early childhood education and their meaning to a child has been recognized.

Love in early education serves as a means to create a learning environment where children can use and develop their own resources, eventually reach the fullest expression of their abilities. One of the key features of a loving teacher and caregiver can be the ability to look at things from a child's point of view (e.g. Zombylas, 2007). This necessitates live interaction and the ability to work in an interactive relationship with children, teacher colleagues, and - increasingly in the modern world - the wider working environment and economic life surrounding the day care system. Our fast changing society requires a new kind of professionalism: the emphasis is on teachers' societal responsibilities and their roles as active future makers (von Wright, 2009; Seidl, \& Friend, 2002). According to Coleman (2009), "recent years have been marked by a notable increase, among researchers and policy makers alike, of interest in the themes of well-being in schools, the relationships between cognitive and non-cognitive aspects of learning, the importance of a 'good childhood', the balancing of instrumental with less readily definable purposes of education, concerns with resilience and with happiness" (p. 281).

Therefore, it seems that endeavors to increase happiness and well-being have become increasingly more popular in educational settings (Webster-Stratton, \& Reid, 2004). Positive psychology offers a suitable theoretical basis for conceptualizing and planning such interventions (Linley et al., 2009; Schiffrin, \& Nelson, 2010). One basic idea is that well-being is not only valuable because it feels good but also because it has beneficial effects (see Diener, \& Seligman, 2004). This point is crucial in early education, too.

We have designed a research project that focuses on love-based leadership. The project was initiated at the University of Lapland in 2011 in collaboration with experts from various fields - education, educational psychology, psychology, administrative sciences, and industrial design (for more information about the project, see http://www.ulapland.fi/lovebasedleadership). The initial and salient focus in our research project was to determine how a selection of scientific approaches might be used in developing research models for re-thinking and designing caring learning environment, students' and children's psychosocial well-being and school communities, and for developing the models of love-based leadership in schooling context (see also Autry, 1991; Caldwell, \& Dixon, 2010). The need for such applications and interventions has been recognized and well justified. According to Seligman et al. (2009, p. 295), "well-being should be taught in school on three grounds: as an antidote to depression, as a vehicle for increasing life satisfaction, and as an aid to 
better learning and more creative thinking." Furthermore, Huebner et al. (2009, pp. 565-566) have defined the features of positive schools: (1) positive schools appreciate the importance of subjective well-being to students' academic success; (2) positive schools work with individual differences in personality, abilities, and interests to maximize compatibility between school experiences and students' needs; (3) positive schools facilitate supportive teacher and peer relationships; and (4) the positive school setting emphasizes instructional tasks that enhance student involvement through offering appropriately challenging, interesting, and voluntary activities.

In this paper, we discuss how the above-mentioned goals could be achieved by employing love-based leadership in early education. The purpose is to increase the positively sensitive actions of love-based leadership through training and activities aimed at promoting mindfulness, gratitude, optimism and resilience at schools. In this article, we will first introduce the concept of love-based leadership and its theoretical foundation. Then, we will outline possibilities to employ the concept in early education settings. The analysis draws on our initial research results and theoretical definitions. Finally, we will discuss the importance, applicability, and relevance of this kind of approach in early education.

\section{WHAT IS LOVE-BASED LEADERSHIP?}

The favorable influence of positive experiences and perceived happiness is widely acknowledged. Happy people are more open, courageous, trusting, and helpful than inhibited, distressed, or depressed people (Seligman et al., 2005; see also Gilpin, 2008). Human happiness and well-being are also socially important: "a happier society overall is beneficial to the greater good" (Gilpin, 2008, p. 3). Unlike unhappy people, happy people are not only friendlier and less materialistic but they also show higher levels of self-regulation (see e.g., Fishbach \& Labroo, 2007; Otake et al., 2006; Polak, \& McCullough, 2006), are more cooperative, pro-social, benevolent, and "other-centered" (Lyubomirsky, Sheldin, \& Schkade, 2005).

Love-based leadership can be discussed through concepts of positive psychology, happiness, well-being, and positivity (Bass, 2000). Caring can be associated with attributes such as benevolence or mindfulness, as well as perseverance and sound judgment. Of these four features of character, the concept of mindfulness originated with Buddha's references to awareness considered in terms of our bodily functions (feelings, thoughts and perceptions) and consciousness itself resulting in the development of wisdom (see e.g., Kabat-Zinn, 2003; Komagata, 2010). Mindfulness can also be defined as a pre-reflective state that includes both self-focused attention and experience (Brown, \& Ryan, 2003). Furthermore, Brown and Ryan (2003) suggest that mindfulness may directly contribute to well-being and happiness (see also Folbre, \& Goodin, 2004).

Therefore, leaders' self-concept is important, not only to enhance their own well-being but also to increase their responsibility to take care of the well-being of those who are under their influence, be they employees, students, pupils, or small children (see also Avolio, \& Gardner, 2005; Avolio, Gardner, Walumbwa, Luthans, \& May, 2004; Diener et al., 1999). In this sense, when considered from the point of view of 
mindfulness, leaders' self-perception can be part of the core of caring leadership. Being aware of their role, the significance of positive experiences and the ability to recognize these experiences enables leaders to enhance happiness and well-being in their workplaces (see also Uusiautti, 2013). Thus, mindfulness comes closer to the idea of minding others' business (see Storh, 2009).

This leads us to a moral dilemma referring to what constitutes the common good and how to raise children to it (Määttä, \& Uusiautti, 2012ab; Uusiautti, \& Määttä, 2012a). Dewey (1909) suggested that the ideas of moral behavior should be transformed into good character. Yet, when talking about a person's desirable characteristics, the problem that arises is how to strike this balance between the natural is and the ethical ought (Kohlberg, \& Mayer, 1972).

Consequently, love-based leadership refers to leaders' ability to use their leadership position in a manner that exemplifies love-based action. In an early education setting, teachers who use love-based leadership consistently exhibit love, forgiveness, and trust in relationships, by dint of which children are likely to respond with engagement, productivity, and satisfaction (see Prewitt, 2003; Rego et al., 2011).

In view of the above presented findings and the growing contribution of positive psychology (e.g. Gable, \& Haidt, 2005; Buss, 2000; Seligman et al., 2005), it seems clear that a "positive-people-management" perspective should be considered both by practitioners and scholars on an international scale (see Calori, 1995). Sensitive leaders develop a culture that demonstrates concern for individual needs (Fairholm, \& Fairholm, 2000). It has been shown that effective leaders are sensitive and responsive to their followers' needs, They provide advice, guidance, as well as emotional and instrumental resources, support employees' creativity, initiative, and autonomy. In addition, sensitive leaders have a desire to meet new challenges and develop and acquire new skills and thus enhance their self-worth and self-efficacy (e.g. Popper, \& Amit, 2009). Happiness not only produces quantitative improvement by increasing efficiency but also a qualitative one by making a better product or outcome by virtue of pride, belief, and commitment.

The role of emotions in the leadership process has attracted increasing interest in recent years and leaders' emotional expressions are typically more important to followers than the objective content of their communication (see Glasø, \& Einarsen, 2008). Emotions and emotional intelligence have even been considered as the core of effective leadership (Goleman, 2006). Therefore, emotions are also given prominence in leadership (Campbell, 2007): authentic leaders are seen "as guided by qualities of the heart (passion and compassion) as by qualities of the mind" (Avolio et al., 2004, p. 805). Furthermore, instead of guiding principles to be blindly followed, an ethics of caring establishes a moral touchstone for decision making (Hoyle, 2002). Love in leaders' work can also be considered from the point of view of the interpersonal nature of emotions. According to Fischer and van Kleef (2010), it is an indisputable fact that emotions are mostly reactions to other people, that emotions take place in settings where other people are present, and that emotions are expressed toward other people and regulated because of other people. Thus, it is necessary for leaders to elicit the feeling of love in order to understand other people as the cause, target, or third-party observer of these emotions. 


\section{TEACHERS AS LOVING LEADERS IN EARLY CHILDHOOD EDUCATION}

According to the traditional definition of platonic love, love is directed toward ideas (instead of bodies, in the sense of erotic love). In particular, what is good and beautiful is seen as the best form of love (e.g., Nehamas, 2007). Moreover, love can be considered an ability (Määttä, \& Uusiautti, 2013; Uusiautti, \& Määttä, 2011; see also Arman, \& Rehnsfeldt, 2006) related to the virtue of humanity (see Seligman, 2002; Seligman et al., 2005), which presents love as representing human kindness, compassion, and affection (e.g. Seligman, Steen, Park, \& Peterson, 2005). Caldwell and Dixon (2009) have defined love, forgiveness, and trust as organizational constructs that produce freedom, empower, and are vital to enhancing followers' self-efficacy.

Authority is often addressed in pedagogical points of view and it has been studied at great length (Delpit, 1988; Pace, \& Hemmings, 2007; Deutsch, \& Jones, 2011). Nevertheless, it has been understood in a contradictory way for education and teaching (Applebaum, 1999; Seidl, \& Friend, 2002; Langford, 2010). Obviously, the relationship between a teacher and a child is asymmetrical because the teacher possesses something that the child does not. According to Hare (1993), the teacher does not have to think that the child is presently his or her equal, but does need to see the child as potentially her/his equal. The purpose of the learning relationship is to help the child develop into an independent and responsible individual. However, children cannot achieve this goal on their own; they need some help and guidance on the part of their teachers (and other adults). Therefore, teachers, who naturally have an authoritarian position, can be seen as leaders who may use their leadership in a love-based manner. Thus, an adult's ability to affect a child is genuine when the authority rather than on power, relies on love and affection (Van Manen, 1991). Harjunen (2009) also defines pedagogical authority through pedagogical interaction. As she notes, pedagogical interaction consists of such characteristics as "trust building", "treating students as human beings", and the "ethics of care and justice".

Määttä and Uusiautti (2012d) have defined the connection between pedagogical love and authority in the following manner:

If pedagogical love and pedagogical authority are based on expertise-based respect, the learning atmosphere is warm and encouraging. Mutual respect supports empathy; students respect the teacher because of his or her expertise and regard the teacher as a sort of safe mainstay that they can rely on. The teacher trusts and believes in the students' abilities, respects their individuality, and helps them to enhance their balanced development and find their own strengths. (p. 29)

What does this mean to love-based leadership in early education? The existence of a good human being can be considered problematic or even impossible because good is confused with perfect. Being a good human being does not mean that one should be totally irreproachable, and moral, that is, non-human. We want to highlight the need to perceive love as the fundamental factor in raising children to be good human beings and that this particular aim is the ultimate purpose of rearing. The main goal therefore is to create a non-threatening environment for learning and development, where children can use and develop their resources (Määttä, \& 
Uusiautti, 2011, 2012d). We also want to stress the significance of early education in the different phases of human development. Since early education settings provide children with the first touch with real communication and collaboration with others, caregivers and teachers have the opportunity to teach children tolerance, respect, and consideration (see e.g., Hollingsworth et al., 2003).

A loving teacher makes sure that children do not lose their trust in their learning and self-worth when facing trouble. In this way, love appears as a goal-oriented action: the teacher plans and implements learning situations that enhance the development of the aforementioned abilities and characteristics (e.g., van Manen, 1991; Hatt, 2005). Basically, love-based leadership in education is considered a working method that involves persistent interest and perseverance to support pupils' development for the sake of themselves and the whole society. In addition, teachers should find a balance between love and authority, and combine them both in a student-specific manner: pedagogical tact is at its strongest in this ability (van Manen, 1991; Määttä, \& Uusiautti, 2012d), emerging from the genuine attachment toward the pupil. At the core, it is the children's vulnerability and defenselessness that make the educator protect them. Therefore, fundamentally, the adult is primarily working for the benefit of the child in this context (Saevi, \& Eilifsen, 2008).

\section{HOW TO USE LOVE-BASED LEADERSHIP IN EARLY CHILDHOOD EDUCATION?}

Positive interventions may be focused on various groups related to early childhood education. Webster-Stratton and Reid (2004) distinguish three ways of intervention: parent education, teacher training, and child training. In this article, the last two are discussed from the early childhood education teacher's point-of-view (for reading more about parental love, see, e.g., Määttä, \& Uusiautti, 2012c).

A teacher who wishes to adopt the ideology of love-based leadership in his or her way of caring and teaching small children must be ready for soul-searching. In practice, it is important that the teacher makes self-assessments: s/he can reflect and observe his or her way of teaching and interacting with children. Becoming aware of one's own style and one's level of tact enables one to move from one quadrant to another, toward an ideal state. It is about the teacher's tact, her/his situational flexibility and her/his capability to discern the various children and personalities (see also Määttä, \& Uusiautti, 2011).

Today's teachers have to adopt a reflective approach in early education. In most educational research, reflection is defined as a useful and necessary method helping to analyze both the teacher's own and others' teaching methods critically and thus leading to better actions in teaching and education (e.g., Mayall, 2000; Swain, 1998). Observing and reflecting on one's own action, and then using this observation and reflection, is a way of bringing about change (Taggart, 2005). Reflection should take place in early childhood education on a daily basis (Happo, Määttä, \& Uusiautti, 2012).

In addition to teachers' reflective practice, love-based leadership includes positively-oriented and well-being promoting actions toward children. The role of a teacher 
who uses love-based leadership is primarily focused on encouraging and rewarding the multitude of talents and strengths a child possesses, chiefly by presenting opportunities to display these talents and strengths every day. In practice, the means are quite simple. They encompass both linking personal strengths to specific festivals and events throughout the school calendar and such activities as the strengths-based classroom, victory logs, and celebrations of "what went well" (see Linley et al., 2009).

Seligman et al. (2009) describe simple exercises that aimed to help students identify their signature strengths and to increase students' use of these strengths in daily life. Moreover, this intervention was to promote resilience, positive emotions and students' sense of meaning or purpose. All these goals were achieved, which made the researchers conclude that well-being should and can be taught at school. Following their observation, we claim that this perspective is also relevant to early childhood education. The point is that well-being could be taught and, with the teacher's lead, children would not only learn about it but their own well-being would increase as well.

Likewise, children can be taught social skills (e.g., Trentacosta et al., 2008; Webster-Stratton, \& Reid, 2004).We also want to emphasize the meaning of early education as the foundation for success in later life, What we have in mind is, for example, its role in providing children with sufficient skills to act in social situations and respect others. According to Webster-Stratton and Reid (2004), strengthening young children's capacity to manage their emotions and behavior, as well as to make meaningful friendships, may serve an important protective function for school success. To be able to learn this type of kindness, children themselves have to experience goodness, caring, acceptance, and tolerance. This forms the core of love-based leadership. Caring teachers are in a position to demonstrate to children how to tolerate failure, insecurity, weakness, and loneliness. Empathy and encouragement help children to identify goodness in themselves and others, regardless of their different backgrounds. Resilience refers to the idea that an individual tends to cope with stress and adversity with the help of positive thinking. According to Fredrickson (2009), positivity is at the heart of human resilience. Its purpose is to enhance resilience in children through practical actions guided by love-based leadership. Instead of concentrating on what is done wrong, teachers can help children discover what they do well and what more could be done (Ryan et al., 1999). This approach doubtless boosts children's self-confidence and positivity, at the same time increasing their tolerance for failure and stimulating them to fix what has been done wrong. Therefore, rather than merely steering clear of hardships and flaws or lowering the academic rigor of early education (see Goleman, 2006), it is essential to learn new ways of seeing things and coping with encountered difficulties.

Thus it is important to provide children with daily experiences of success. If the mastery of information and skills to be learned is to lead toward success and if positive emotion is one of the keystones of learning, it seems reasonable to pay attention to this viewpoint in education (Chafouleas, \& Bray, 2004). Fredrickson (2001), for instance, considers pride as a distinct positive emotion that follows personal achievements, since in order to feel pride, one has to succeed and, as a result, one gains the experience of success. This kind of experience can be promoted by adjusting goals and planning learning tasks in a way that allows every child to have the sense of achieving a goal. 
Teachers who use love-based leadership try to find a balance between children's abilities, chances, and challenges. We strongly believe this is likely to lead to better learning, development, performance, contentment, higher motivation, and the sense of self-efficacy that may have a far-reaching positive influence on children's later life.

\section{DISCUSSION}

Positive psychology, which deals with such issues as well-being, happiness, the quality of life and positive feelings, has been concerned with investigating positive characteristics and feelings as well as the institutions that facilitate the discovery of positive feelings and strengths (Seligman et al., 2005; Seligman, Parks, \& Steen, 2004). Clearly, this scholarly field lays foundations for the fundamental aims of love-based leadership and teaching. Transmitting this kind of attitude to our children could be the main guideline in the upbringing of children: this is what love fundamentally is and children will learn it only if we-educators, parents, and other people who play a significant role in children's life-set an example by directing our mindful and loving action at children and other people as well.

Already at the very first level of education, love-based leadership could therefore act as a means to lead and guide children toward "the Meaningful Life", as Seligman calls it (see e.g. Seligman et al., 2009, p. 296). As Greer (2002, p. 8) felicitously puts it, "When a leader communicates his trust in and respect for followers' ability to perform a given task, their internal motivation takes over and drives the followers to succeed in their assignments, and the process moves forward." If considered from the point of view of love-based leadership, Greer's remark goes hand in hand with the ideas presented about teachers' love-based action in education. As caring pedagogical authorities, teachers have the possibility to help bringing out the best in children. Then, the process moves forward. Noteworthy, rather than focusing solely on learning and performing, it also entails discovering and using children's signature strengths and promoting well-being and happiness in life.

\section{CONCLUSION. THE INCREASING IMPORTANCE OF QUALITY EARLY CHILDHOOD EDUCATION}

The current Finnish family policy rests on three pillars: a child-oriented society, thriving families with children, and the prevention of social exclusion (Ministry of Social Affairs and Health [MSAH], 2006). In services created for families with children, the focus ever since the 1970s has been on developing child care systems for small children and on improving the opportunities for parents both to spend more time with their children and to make it easier for women to return to work. In the vast majority of Finnish families with children under school age, both parents work full-time. Under these circumstances, a reliable and safe day care system is of vital importance (MSAH, 2006). Finland uses the Nordic welfare state principles and methods, which are based on the state's responsibility for its citizens (Heinämäki, 2008; Määttä, \& Uusiautti, 2012a). But in order to meet future demands, there is a need 
for social change, new requirements of tolerance, cooperation skills, and internationalism, and new approaches to teachers' and educators' work. The Finnish early childhood education system offers favorable premises for introducing love-based leadership in early education and the method should also be included in the curriculum of early childhood education teachers.

All in all, the ability to create happiness for life is an important attribute of a good educator and teacher. As Gammage (2006) puts it eloquently:

We do not need childcare, or kindergarten, because imaginary "feckless" women go to work outside the home; we need it from necessity, as secure and loving provision in settings which support and supplement the family, and which enable rich attachments and happy learning experiences for our children. (p. 241)

Given the idea of love as a learnable ability that consists of emotions, action, knowledge and skills (Uusiautti, \& Määttä, 2011), love-based leadership as introduced in this article seems a worthy approach in early education of today and in the future.

\section{REFERENCES}

Act on Children's Day Care. (1973/36). Retrieved from

http:/ / www.finlex.fi/fi/laki/ajantasa/1973/19730036?search\%5Btype\%5D=pika\&search\%

5Bpika\%5D=laki\%20lasten\%20p\%C3\%A4iv\%C3\%A4hoidosta

Arman, M., \& Rehnsfeldt, A. (2006). The presence of love in ethical caring. Nursing Forum, 41(1), 4-12.

Autry, J. A. (1991). Love and profit: The art of caring leadership. New York, NY: Morrow.

Avolio, B. J., \& Gardner, W. L. (2005). Authentic leadership development: Getting to the root of positive forms of leadership. The Leadership Quarterly, 16(3), 315-338.

Avolio, B. J., Gardner, W. J., Walumbwa, F. O., Luthans, F., \& May, D. R. (2004). Unlocking the mask: a look at the process by which authentic leaders impact follower attitudes and behaviours. Leadership Quarterly, 15, 801-823.

Bass, B. M. (2000). The future of leadership in learning organizations. Journal of Leadership Studies, 7, 18-40.

Blay, J.A., \& Ireson, J. (2009). Pedagogical beliefs, activity choice and structure, and adult-child interaction in nursery classrooms. Teaching and Teacher Education, 25(8), 1105-1116.

Brown, K. W., \& Ryan, R. M. (2003). The benefits of being present: mindfulness and its role in psychological well-being. Journal of Personality and Social Psychology, 84, 822-848. doi: 10.1037/0022-3514.84.4.822

Buss, D. M. (2000). The evolution of happiness. American Psychologist, 55(1), 15-23.

Caldwell, C., \& Dixon, R. D. (2010). Love, forgiveness, and trust: critical values of the modern leader. Journal of Business Ethics, 93, 91-101. doi: 10.1007/s10551-009-0184-z

Calori, R. (1995). Management in Europe: Learning from different perspectives. European Management Journal, 13(1), 58-66.

Campbell, C. R. (2007). On the journey toward wholeness in leader theories. Leadership E Organization Development Journal, 28(2), 137-153.

Chafouleas, S. M., \& Bray, M. A. (2004). Engagement, disengagement, coping, and catastrophe. In: A. J. Elliot, \& C. S. Dweck (eds.), Handbook of Competence and Motivation (pp. 527-547). New York, NY: The Guilford Press.

Coleman, J. (2009). Well-being in schools: empirical measure, or politician's dream? Oxford Review of Education, 35(3), 281-292. DOI: 10.1080/03054980902934548

Decree on Children's Day-care. (239/1973). Retrieved from http://www.finlex.fi/fi/laki/ajanta sa $/ 1973 / 19730239$ ? search $\%$ B type $\% 5$ D =pika\&search $\% 5$ Bpika $\% 5 D=$ asetus $\% 201$ asten $\% 20$ p\%C3\%A4iv\%C3\%A4hoidosta

Delpit, L. D. (1988). The silenced dialogue; Power and pedagogy in educating other people's children. Harvard Educational Review, 58(3), 280-298. 
Deutsch, N. L., \& Jones, J. N. (2011). 'Show me an ounce of respect': Respect and authority in adultyouth relationships in after-school programs. Journal of Adolescent Research, 23(6), 667-688. doi: $10.1177 / 0743558408322250$

Dewey, J. (1909). Moral principles in education. Cambridge, MA: The Riverside Press.

Diener, E., \& Seligman, M. E. P. (2004). Beyond money: toward an economy of well-being. Psychological Science in the Public Interest, 5(1), 1-31.

Diener, E., Suh, E. M., Lucas, R. E., \& Smith, H. L. (1999). Subjective well-being: three decades of progress. Psychological Bulletin, 125, 276-302.

Fairholm, M. R., \& Fairholm, G. (2000). Leadership amid the constraints of trust. Leadership \& Organization Development Journal, 21(1/2), 102-109.

Fishbach, A., \& Labroo, A. A. (2007). Be better or be merry: how mood affects self-control. Journal of Personality and Social Psychology, 93(2), 158-173.

Fischer, A. H., \& van Kleef, G. A. (2010). Where have all the people gone? A plea for including social interaction in emotion research. Emotion Review, 2(3), 208-211. doi: 10.1177/1754073910361980

Folbre, N., \& Goodin, R. E. (2004). Revealing altruism. Review of Social Economy, 62(1), 1-25.

Fredrickson, B. L. (1998). What good are positive emotions?. Review of General Psychology, 2(3), 300-319.

Fredrickson, B. L. (2009). Positivity. Groundbreaking research reveals how to embrace the hidden strength of positive emotions, overcome negativity, and thrive. New York, NY: Random House.

Gable, S. L., \& Haidt, J. (2005). What (and why) is positive psychology? Review of General Psychology, 9(2), 103-110.

Gammage, P. (2006). Early childhood education and care: politics, policies and possibilities. Early Years, 26(3), 235-248.

Gilpin, J. M. (2008). Teaching happiness. The role of positive psychology in the classroom. Pell Scholars and Senior Theses, 12, 1-23.

Glasø, L., \& Einarsen, S. (2008). Emotion regulation in leader-follower relationships. European Journal of Work and Organizational Psychology, 17(4), 482-500. doi: 10.1080/13594320801994960

Goleman, D. (2006). The socially intelligent. Educational Leadership, 64, 76-81.

Greer, M. E. (2002). Trust seals leadership. Professional Safety, 47(5), 8.

Happo, I. (2006). Varhaiskasvattajan asiantuntijuus. Asiantuntijaksi kehittyminen Lapin läänissä [Expertise of early childhood educators. Growth of expertise in early childhood educators in the Province of Lapland]. Acta Universitatis Lapponiensis 98. Rovaniemi: University of Lapland.

Happo, I., Määttä, K., \& Uusiautti, S. (2012). Experts or Good Educators - or Both? The Development of Early Childhood Educators' Expertise in Finland. Early Child Development and Care, 182(3-4), 487-504. doi:10.1080/03004430.2011.646719

Hare, W. (1993). What makes a good teacher: Reflections on some characteristics central to the educational enterprise. London \& Ontario: The Althouse Press.

Harjunen, E. (2009). How do teachers view their own pedagogical authority? Teachers and Teaching: theory and practice, 15(1), 109-129. doi: 10.1080/13540600802661345

Hatt, B. E. (2005). Pedagogical love in the transactional curriculum. Journal of Curriculum Studies, 37(6), 671-688. doi: 10.1080/00220270500109247

Heinämäki, L. (2008). Early childhood education in Finland. Potsdam: Liberales Institut. Retrieved from http://pro-kopf.de/fileadmin/Downloads/OC_39-Heinaemaeki-ECE_in_Finland.pdf

Hollingsworth, L. A., Didelot, M. J., \& Smith, J. O. (2003). REACH Beyond Tolerance: A Framework for Teaching Children Empathy and Responsibility. Journal of Humanistic Counseling, Education \& Development, 42(2), 139-151. doi: 10.1002/j.2164-490X.2003.tb00002.x

Hoyle, J. R. (2002). Leadership and the force of love. Six keys to motivating with love. Thousand Oaks, CA Sage.

Huebner, E. S., Gilman, R., Reschly, A. L., \& Hall, R. (2009). Positive schools. In: S. J. Lopez, \& C. R. Snyder (eds.), Oxford handbook of positive psychology (pp. 561-568). Oxford: Oxford University Press.

Kabat-Zinn, J. (2003). Mindfulness-based interventions in context: past, present, and future. Clinical Psychology: Science and Practice, 10(2), 144-156. doi: 10.1093/clipsy/bpg016

Kohlberg, L., \& Mayer, R. (1972). Development as the aim of education. Harvard Educational Review, 42(4), 449-496.

Komagata, N. (2010). Attachment and non-attachment: attachment theory and Buddhism. Retrieved from http://nobo.komagata.net/pub/Komagata09-Xtachment.html, http://nobo.komagata.net/pub/ Komagata09-Xtachment.pdf. 
Linley, P. A., Joseph, S., Maltby, J., Harrington, S., \& Wood, A. M. (2009). Positive psychology applications. In S. J. Lopez \& C. R. Snyder (Eds.), Oxford handbook of positive psychology (pp. 35-47). Oxford: Oxford University Press.

Lyubomirsky, S., Sheldin, K. M., \& Schkade, D. (2005). Pursuing happiness: the architecture of sustainable change. Review of General Psychology, 9(2), 111-131.

Mayall, B. (2000). The sociology of childhood in relation to children's rights. The International Journal of Children's Rights, 8, 243-259.

Määttä, K., \& Uusiautti, S. (2011). Pedagogical love and good teacherhood. In Education, 17(2). Retrieved from: http://ineducation.ca/article/pedagogical-love-and-good-teacherhood

Määttä, K., \& Uusiautti, S. (2012a). How do the Finnish family policy and early education system support the well-being, happiness, and success of families and children? Early Child Development and Care, 182(3-4), 291-298. doi:10.1080/03004430.2011.646718

Määttä, K., \& Uusiautti, S. (2012b). How to raise children to be good people? Analytic Teaching and Philosophical Praxis, 33(1), 83-91.

Määttä, K., \& Uusiautti, S. (2012c). Parental love -Irreplaceable for children's well-being. Global Journal of Human Social Sciences, 12(10), 1-8.

Määttä, K., \& Uusiautti, S. (2012d). Pedagogical authority and pedagogical love - connected or incompatible? International Journal of Whole Schooling, 8(1), 21-39.

Määttä, K., \& Uusiautti, S. (2013). Many faces of love. Rotterdam: Sense Publishers.

Ministry of Social Affairs and Health. (2006). Finland's family policy. Helsinki: Ministry of Social Affairs and Health. Retrieved from http://www.stm.fi/en/publications/publication/_julkaisu/1058023\#en

National Curriculum Guidelines on Early Childhood Education and Care in Finland. (2003). Guidelines 56. Helsinki: Statistics Finland. Retrieved from http://kasvunkumppanit.thl.fi/thl-client/ pdfs/267671cb-0ec0-4039-b97b-7ac6ce6b9c10502

Nehamas, A. (2007). 'Only in the contemplation of beauty is human life worth living' Plato, symposium 211d. European Journal of Philosophy, 15(1), 1-18.

Otake, K., Shimai, S., Tanaka-Matsumi, J., Otsui, K., \& Fredricsson, B. L. (2006). Happy people become happier through kindness: a counting kindnesses intervention. Journal of Happiness Studies, 7(3), 361-375.

Pace, J. L., \& Hemmings, A. (2007). Understanding authority in classrooms: A review of theory, ideology, and research. Review of Educational Research, 77(1), 4-27.doi: 10.3102/003465430298489

Polak, E. L., \& McCullough, M. E. (2006). Is gratitude an alternative to materialism. Journal of Happiness Studies, 7, 343-360.

Popper, M., \& Amit, A. (2009). Attachment and leader's development via experiences. The Leadership Quarterly, 20(5), 749-763.

Prewitt, V. (2003). Leadership development for learning organizations. Leadership \& Organization Development Journal, 24(2), 58-61. doi: 10.1108/01437730210463242

Rego, A., Ribeiro, N., Pina, M., \& Jesuino, J. C. (2011). How happiness mediates the organizational virtuousness and affective commitment relationship. Journal of Business Research, 64(5), 524-532.

Ryan, F. J., Soven, M., Smither, J., Sullivan, W. M., \& Vanbuskirk, W. R. (1999). Appreciative inquiry: Using personal narratives for initiating school reform. Clearing House, 72(3), 164-167.

Saevi, T., \& Eilifsen, M. (2008). 'Heartful' or 'heartless' teachers? Or should we look for the good somewhere else? Considerations of students' experience of the pedagogical good. Indo-Pacific Journal of Phenomenology, 8, 1-14.

Schiffrin, H. H., \& Nelson, K. Æ S. (2010). Stressed and happy? Investigating the relationship between happiness and perceived stress. Journal of Happiness Studies, 11, 33-39. doi: 10.1007/s10902-008-9104-7

Seidl, B., \& Friend, G. (2002). Leaving authority at the door: equal-status community-based experiences and the preparation of teachers for diverse classrooms. Teaching and Teacher Education, 18, 421-433.

Seligman, M. E. P. (2009). Positive education: positive psychology and classroom interventions. Oxford Review of Education, 35(3), 293-311. doi: 10.1080/03051980902934563

Seligman, M. E. P., Parks, A. C., \& Steen, T. A. (2004). A balanced psychology and a full life. Philosophical Transactions of the Royal Society B359, 1379-1381.

Seligman, M. E. P., Steen, T. A., Park, N., \& Peterson, C. (2005). Positive psychology progress. Empirical validation of interventions. American Psychologist, 60(5), 410 - 421.

Storh, K. (2009). Minding others' business. Pacific Philosophical Quarterly, 90, 116-139.

Swain, J. (1998). Studying teachers' transformations: reflections as methodology. The Clearing House, 72(1), 29-34. 
Taggart, G. (2005). Promoting reflective thinking in teachers: 50 action strategies. Thousand Oaks, CA: Corwin Press.

Trentacosta, C. J., Izard, C. E., Mostow, A. J., \& Fine, S. E. (2006). Children's emotional competence and attentional competence in early elementary school. School Psychology Quarterly, 21(2), 148-170. doi: 10.1521/scpq.2006.21.2.148

Uusiautti, S. (2013). An action-oriented perspective on caring leadership: a qualitative study of higher education administrators' positive leadership experiences. International Journal of Leadership in Education: Theory and Practice. Retrieved from

http://dx.doi.org/10.1080/13603124.2013.770077

Uusiautti, S., \& Määttä, K. (2011). The ability to love - a virtue-based approach. British Journal of Educational Research, 2(1), 1-19.

Uusiautti, S., \& Määttä, K. (2012a). Can teachers teach children how to be moral? British Journal of Education, Society E Behavioural Science, 2(3), 260-270.

Uusiautti, S., \& Määttä, K. (2012b). How to employ love-based leadership at school? Journal of Social Sciences, in press.

van Manen, M. (1991). The tact of teaching: the meaning of pedagogical thoughtfulness. London: Althouse Press.

von Wright, M. (2009, March). The shunned essentials of pedagogy: authority, love and mystery. Paper presented at Nordic Philosophy of Education Network NERA Annual Meeting, Trondheim, March 5-7th 2009. Retrieved from: http:/ / oru.diva-portal.org/smash/record.jsf?pid=diva2:212954

Webster-Stratton, C., \& Reid, M. J. (2004). Strengthening social and emotional competence in young children-the foundation for early school readiness and success: incredible years classroom social skills and problem-solving curriculum. Infants \& Young Children, 17(2), 96-113.

Zombylas, N. (2007). Emotional ecology: The intersection of emotional knowledge and pedagogical content knowledge in teaching. Teaching and Teacher Education, 23, 355-367. 